\title{
A Vajdaságból Magyarországra irányuló tanulmányi célú migráció
}

\author{
Educational migration from Vojvodina to Hungary
}

TAKÁCS ZOLTÁN, TÁTRAI PATRIK, ERŐSS ÁGNES

KULCSSZAVAK: agyelszívás, nemzetpolitika, migrációs döntések, közoktatás, felsőoktatás

\begin{abstract}
ABSZTRAKT: Írásunkban a Vajdaságból Magyarországra irányuló tanulmányi célú migráció értelmezési kereteit, történetét, földrajzi jellemzőit, a migrációt befolyásoló tényezőket, valamint a migrációs döntések hátterét mutatjuk be. A jelenséget föként az agyelszívás elméletét alkalmazva és mindkét ország/régió szemszögéből nézve vizsgáljuk. Mivel a vizsgált jelenséget nagymértékben befolyásolják a különböző (magyar, illetve vajdasági magyar) nemzetpolitikák, ezért ezeket kiemelt fontosságúként ismertetjük. Tanulmányunk első fele főként statisztikai adatokra épülő makroszintű elemzés. Az így kialakuló képet interjúkból nyert tapasztalatainkkal igyekeztünk árnyalni, és bemutatni az egyének és családok továbbtanulásról és letelepedésről szóló döntéseit.

Az elmúlt két évtizedben a Vajdaságból Magyarországra irányuló tanulmányi célú migráció belső szerkezete átalakult, a közoktatásról a hangsúly egyértelműen a felsőoktatásra helyeződött át - összhangban a regionális és globális folyamatokkal. E migráció elsősorban a vajdasági magyar kisebbséget, annak is főként magyar identitású, magasan kvalifikált csoportjait érinti, így vajdasági magyar szemszögből a folyamat egyértelműen az agyelszívás veszélyeit hordozza magában. Napjainkban a vizsgált tanulmányi célú migráció egyszerre etnikai és gazdasági meghatározottságú folyamat. A kilencvenes évek háborús viszonyainak elmúltával is tartósak azok a vonzó és taszító tényezők, illetve azok a határon átnyúló, transznacionális migráns hálózatok, amelyek táplálják, tehát nem csak segítik, de támogatott, legitim családi és egyéni stratégiává is teszik a tanulmányi célú migrációt. Bár a transznacionális migráció e formája a kimenetelét tekintve nyitott (áttelepedés, visszatérés, harmadik országba költözés, cirkuláció), az esetek többségében a szülőföldről való „végleges” távozás első lépcsőfokának tekinthető.
\end{abstract}

KEYWORDS: brain drain, nation policy, migration decisions, public education, higher education

ABSTRACT: This study tries to present the theoretical framework, history, geographical peculiarities and influencing factors of the educational migration from Vojvodina to Hungary as well as the background of decisions about migration. We approach the issue from the brain drain theory to understand the phenomenon, and we analyse it from each region's perspective. The first part of the paper is mostly based on statistical data which we try to illustrate later by including presentations of individuals' and families' decisions about education and resettlement in Hungary (through interviews with Vojvodina Hungarian students in Hungary).

Considering the migration between Serbia and Hungary, educational migration (with a focus on higher education) became one of the most significant types. The migration under

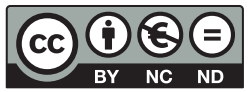


study concerns primarily the Vojvodina Hungarian minority - first of all those with high qualifications. So, from the Vojvodina Hungarian point of view, the process involves the risk of a brain drain.

At present, educational migration is determined by both ethnic and economic factors. The push and pull factors that emerged during the Balkan wars in the 1990s as well as the transnational migrant networks, which promote and support migration, seem to have remained stable. Although the outcome of such transnational migration is considered to be open (resettlement, return, move to a third country, circulation) our research indicates that, in the majority of cases, educational motives constitute the first step towards permanently leaving the native country.

Since the beginning of the two-decade-old transnational educational migration, Hungarian nation policy (as defined by the Hungarian ministry of foreign affairs) which also affects Hungarians living outside Hungary, and its related educational policy attempt to influence the nature and extent of this form of migration (e.g. through the scholarship and/or fee-paying system). However, this policy, with its associated instruments - despite its intention is unable to influence educational migration directly and basically. The present Hungarian nation policy is controversial, and we could not establish which its most important purpose is: to help Hungarian minority communities sustain a livelihood in their native country or to implicitly encourage resettlement. The Vojvodina Hungarian nation policy could not reach its goals (education in the native country and return from abroad) yet. However, the results of the change of the scholarship system will be seen only a few years later.

\section{A tanulmányi célú migráció értelmezési keretei}

A tanulmányi célú migrációt a migrációs rendszeren belüli növekvő jelentőségének köszönhetően élénk kutatói érdeklődés kíséri az ezredforduló óta. Legfontosabb mozgatórugója globális szinten az országok, régiók közti fejlettségbeli különbség, így földrajzilag koncentráltan elsősorban az angolszász országok felé irányul, ami egyúttal az angol nyelvtudás fontosságára, globális gazdaságban betöltött szerepére is rávilágít (Rédei 2006, 233.).

A tanulmányi célú migráció sokszor elválaszthatatlan a munka- és karriercélú migrációtól, hiszen a hallgatók a diploma megszerzése után gyakran a célországban maradnak, és ott lépnek be a munkaerőpiacra. Ezért Salt $(2005,31$.$) a$ tanulmányi célú migrációt a magasan képzettek egyik vándorlási típusának tartja, míg más szerzők (lásd többek között Iredale 2001; Mahroum 2001; OECD 2002 idézi Rédei 2006, 233.) a magasan képzettek migrációját előkészíto, előjelző lépésként, vagy a globalizáció fokmérőjeként is értelmezik (részletesen lásd Rédei 2009, 24-28.).

Míg korábbi írásunkban (Erőss, Filep, Rácz, Tátrai, Váradi, Wastl-Walter 2011) a tanulmányi célú migrációt a transznacionalizmus elméleti keretébe ágyazva vizsgáltuk, addig jelen munkánkban főként az agyelszívás elmélete felől közelítjük meg a kérdéskört. Ugyanakkor korábbi munkánk és a szakirodalom alapján hangsúlyozzuk, hogy a vizsgált jelenség egyben a transznacionális migráció jeleit hordozza (pl. transznacionális migráns hálózatok). ${ }^{1}$ 
Tanulmányunk első fele, amely a vizsgált folyamat mértékét, irányát, társadalmi, gazdasági, (nemzet)politikai kontextusát mutatja be, elsősorban - de nem kizárólagosan - az agyelszívás (vagy magyarországi szempontból az „agygyarapodás") megközelítését alkalmazza. Agyelszívás ${ }^{2}$ alatt hagyományosan azt a jelenséget értjük, amikor a magasan képzett munkaerő vándorol, általában a fejletlenebb országból a fejlettebb országba; a migráció kiváltó oka tehát a gazdasági, fejlettségbeli különbség (Egedy, Kovács 2011, 164.). Ez a küldő ország szempontjából agyelszívás, a fogadó felől tekintve viszont „agygyarapodás”. Az agyelszívás a tanulmányi célú migrációban akkor valósul meg, ha e tanulók alacsony számban térnek vissza, vagy ha a kibocsátó ország „,agyvonzó” képessége gyenge (lásd Csanády, Személyi 2006, 80.). Magyarországra leginkább az „agycsere" folyamata jellemzo", mivel a magasan képzettek elvándorlását a külföldről érkező képzettek (pl. határon túli magyarok, vagy akár nyugat-európai „kreatívok” - utóbbiról lásd Egedy, Kovács 2011) migrációja valamelyest ellensúlyozza. Ezzel szemben Szerbia és különösen a vizsgált közösség, a vajdasági magyarok esetében az agyelszívás ${ }^{3}$ létező jelenség, hiszen etnikai, nyelvi, kulturális kisebbségi közösségként utánpótlást Szerbiából nem nyerhet, viszont a fejlettségi különbségek, valamint a határon túli magyar kisebbség és az anyaország viszonya miatt a migrációs kapcsolatok Magyarországgal alapvetően egyirányúak. Éppen ezért általánosságban is, de a vajdasági magyar közösségre nézve különösen igaz, hogy a kibocsátó közeg számára a legnagyobb értéket azok a diákok képviselik, akik külföldi tanulmányaik befejeztével hazatérnek (brain regain) (Egedy, Kovács 2011; Gürüz 2008). Ezzel szemben a Magyarországon maradó vajdasági diákok Szerbia, de elsősorban a vajdasági magyar közösség számára veszteséget jelentenek. Az „intellektuális tőke szétszóródása”, a szakemberhiány - a demográfiai gondok mellett - számos további problémát okozhat, és szerepe van a lassuló gazdasági fejlődésben, a munkatermelékenység csökkenésében, az innováció hiányában, a versenyképesség fokozatos elvesztésében (Csanády, Személyi 2006; Gábrity Molnár 2008a; Gredelj 2006). Nem meglepő, hogy időről időre - például napjainkban Magyarországon - felmerül az agyelszívás/kivándorlás okozta veszteség megfizettetésének gondolata (pl. tandíj-megfizetési kötelezettség kivándorlás esetén), ${ }^{4}$ ám Csanády és Személyi (2006, 82.) szavaival „nem keveset von le e megoldások értékéből, hogy még sehol a világon nem alkalmazták élesben".

Az agyelszívás (és a transznacionalitás) általános jelensége mellett a Magyarországra irányuló tanulmányi célú migráció sajátossága az, hogy az ide érkező diákok közel felénél az etnicitás szerepet játszik a vándorlási folyamatban. Magyarország nem csak azért vonzza a szomszédos országok magyar hallgatóit, mert itt a képzés esetleg magasabb színvonalú, vagy mert hosszabb távon tervezve a vajdaságiak számára magasabb életszínvonalat nyújthat az ország. Az etnikai, nyelvi, kulturális hasonlóság, az érzelmi kötődés és Magyarország mint „anyaország” ugyancsak meghatározó vonzerők. 
A Kárpát-medencét behálózó tanulási és karriermigráció hátterében Feischmidt és Zakariás $(2010,161$.) két fó tényezőt azonosít: „az egyéneket a centrumba vonzó tágabb mobilitási perspektívák valamint a kisebbségi státus hátrányai a többségi társadalom mobilitási pályáin együttesen vezetnek az elmozduláshoz.” Hasonlóan látja a kérdést Gödri is $(2010,34$.), aki szerint ,a kisebbségben élő magyarok számára (...) a »centrum « irányába történő földrajzi elmozdulás sok esetben mint a társadalmi mobilitás lehetséges csatornája" jelenik meg. Ebben a közegben az etnicitás, a származás, a magyar nyelv és kultúra ismerete a migráció során kulturális és szociális tőkeként mobilizálható (Erőss, Filep, Rácz, Tátrai, Váradi, Wastl-Walter 2011, 5.; Feischmidt, Zakariás 2010, 152.). Bár a vizsgált migráció átível a nemzetállami határokon, az említett hasonlóság miatt egyes szerzők szerint a környező országokból Magyarországra irányuló migráció „valahol a belföldi és a nemzetközi migráció között helyezhető el” (Gödri 2005, 79.).

\section{Tanulmányi célú migráció a Vajdaságból Magyarországra, nemzetpolitikai erőtérben}

\section{Magyarországi szemszögböl}

Napjainkban a tanulmányi célú migráció egyre jelentősebb részesedéssel bír az összes Magyarországra irányuló vándorláson belül. E folyamat jól illeszkedik mind a regionális, mind a globális trendekbe (Rédei 2009).

A 2011/2012-es tanévben a Magyarországon nappali képzésben tanuló több mint 30 ezer külföldi állampolgárságú diák a teljes hallgatói létszám 1,6\%át tette ki. Ez az arány az életkor előrehaladtával egyre nő, azaz az óvodások mindössze $0,7 \%$-a, az általános iskolások 0,8\%-a és a középiskolások 1\%-a külföldi, ugyanakkor a felsőoktatásban már 7,1\% a Magyarországon kívülről érkezők részesedése. ${ }^{5}$ Míg az elmúlt másfél évtizedben az első három kategóriában a külföldiek számának stagnálása, enyhe emelkedése tapasztalható, addig a felsőoktatásban résztvevők száma és aránya dinamikusan nő. ${ }^{6}$

A Magyarországra tanulmányi céllal érkezők legfőbb sajátossága, hogy a legnagyobb csoportjukat - időben változó mértékben - a szomszédos országokból érkező magyar tanulók adják. Az 1990-es években arányuk 50\% körül ingadozott az összes külföldi diák között, azonban a 2001/2002-es tanévben regisztrált csúcspont (59\%) óta folyamatosan csökken a részesedésük, így napjainkban már csak a teljes hallgatói létszám 38\%-a határon túli magyar, miközben abszolút számuk nem csökken (EMMI 2012; NEM 2011). Ez az arány jelentősen elmarad a szomszédos országból érkező összes migránsnak a teljes migráns népességen belüli arányához viszonyítva, amely a KSH adatai szerint a rendszerváltás óta $50-80 \%$ között mozog (2012-ben 54\%). 
A szomszédos országokból érkező, Magyarországon tanuló diákok száma elsősorban a kibocsátó országok magyar közösségének nagyságától függ (tehát sorrendben Romániából, Szlovákiából, Szerbiából és Ukrajnából érkezik a legtöbb diák), azonban ha e közösségek nagyságához viszonyítjuk a diákok számát, akkor arányaiban éppen fordított a sorrend. Ha a Magyarországon tanulók számát az adott országból érkezett Magyarországon élő migránsok számához viszonyítjuk, akkor kirajzolódik, hogy a Szlovákiából érkezők körében sokkal jelentősebb a tanulmányi célú migráció, mint a többi ország (sorrendben Szerbia, Ukrajna és Románia) esetében. Megállapítható az is, hogy időben és országonként jelentősen változik a kereslet a magyarországi oktatás egyes fajtái (köz- vagy felsőoktatás) iránt, ami mind a küldő, mind a fogadó ország társadalmi-gazdasági viszonyainak, valamint támogatási rendszereinek is függvénye. Előbbi behatárolja az oktatás minőségét, presztízsét, az oktatás iránti igényeket, utóbbi pedig - ösztöndíjrendszereken, illetve különböző anyagi és nem anyagi támogatásokon keresztül - szabályozni, befolyásolni igyekszik a Kárpát-medencei magyar tanulmányi migrációt.

Szerbiában (illetve korábban Jugoszláviában, Szerbia és Montenegróban) a magyar népesség magyarországi taníttatási stratégiája jelentősen eltér(t) a többi Magyarországgal szomszédos országétól, ami elsősorban a délszláv háborúk következménye. Bár a vajdasági magyarok tanulmányi célú migrációja már az 1980-as években megjelent, számottevővé csak 1991-től, a délszláv polgárháború kitörésétől vált. 1988 és 1994 között a Magyarországon tanuló külföldi diákok 10,3\%-a Jugoszláviából származott (Tóth 1997), később, a délszláv polgárháború után átmenetileg visszaesett számuk és arányuk, de az 1999-es koszovói válság (NATO-bombázások) idején ismét jelentősen megnőtt a Magyarországon tanuló vajdasági fiatalok száma. ${ }^{7}$ E kiugró értékek (1. táblázat) hátterében fóként a biztonságra való törekvés állt. Ebben az időszakban a magyarországi közoktatásban tanuló szerb állampolgárok száma jóval magasabb volt, mint napjainkban. A 2000-es években tapasztalt csökkenésben közrejátszhatott az is, hogy a közoktatási törvény 2007-es módosítása után a harmadik országbeli tanköteles gyerekek akkor részesülhetnek ingyenes oktatásban, ha szüleik igazolni tudják, hogy Magyarországon jövedelemmel rendelkeznek és lakhatásuk biztosított. Korábban a magyar állam az ő képzésüket is normatívával támogatta (Erőss, Filep, Rácz, Tátrai, Váradi, Wastl-Walter 2011, 8.).

Ezzel szemben a magyarországi felsőoktatásban tanuló szerb állampolgárok száma az 1990-es években alig haladta meg a középiskolásokét, a koszovói válság alatti első csúcspontja után csak 2004-től kezdett el ismét növekedni, és a 2011/2012-es tanévben érte el eddigi legmagasabb értékét (1. táblázat).

A vajdasági fiatalok Magyarországra irányuló felsőoktatási migrációja annak ellenére töretlen, hogy az elmúlt két évtizedben a magyarországi kormányzatok igyekeztek a határon túli magyar közösségek értelmiségének képzését és szülöföldön maradását támogatni. Bár a szülőföldön maradás továbbra is deklarált cél (lásd az Alaptörvény D cikkét), a magyar támogatáspolitika periodikus változása, 
1. táblázat: Szerb állampolgárságú óvodások, tanulók és hallgatók nappali tagozaton Magyarországon ${ }^{8}$ Preschoolers, pupils, students (in normal degree programmes) with Serbian citizenship in Hungary

\begin{tabular}{cccccccc}
\hline Tanév & Óvoda & $\begin{array}{c}\text { Általános } \\
\text { iskola }\end{array}$ & Szakiskola & $\begin{array}{c}\text { Közép- } \\
\text { iskola }\end{array}$ & $\begin{array}{c}\text { Felsö- } \\
\text { oktatási } \\
\text { intézmény }\end{array}$ & Összesen & $\begin{array}{c}\text { Részesedés a Magyar- } \\
\text { országon tanuló összes } \\
\text { külföldi diákból (\%) }\end{array}$ \\
\hline $1995 / 1996$ &.. & 376 & 92 & 572 & 596 & 1636 & 14,7 \\
$1996 / 1997$ &.. & 339 & 92 & 540 &.. &.. &.. \\
$1997 / 1998$ &.. & 308 & 89 & 488 &.. &.. &. \\
$1998 / 1999$ &.. & 295 & 73 & 499 & 281 & 1148 & 8,3 \\
$1999 / 2000$ &.. & 395 & 84 & 676 & 843 & 1998 & 12,8 \\
$2001 / 2002$ & 55 & 306 & 49 & 634 & 822 & 1866 & 10,1 \\
$2002 / 2003$ & 65 & 307 & 80 & 556 & 796 & 1804 & 8,4 \\
$2003 / 2004$ & 30 & 282 & 73 & 511 & 663 & 1559 & 7,1 \\
$2004 / 2005$ & 29 & 222 & 72 & 509 & 714 & 1546 & 6,9 \\
$2005 / 2006$ & 33 & 232 & 71 & 465 & 755 & 1556 & 6,8 \\
$2006 / 2007$ & 35 & 194 & 101 & 485 & 765 & 1580 & 6,8 \\
$2007 / 2008$ & 35 & 170 & 81 & 421 & 871 & 1578 & 6,8 \\
$2008 / 2009$ & 38 & 139 & 47 & 380 & 868 & 1472 & 6,1 \\
$2009 / 2010$ & 39 & 211 & 71 & 401 & 1009 & 1731 & 7,0 \\
$2010 / 2011$ & 38 & 174 & 60 & 353 & 1136 & 1761 & 6,8 \\
$2011 / 2012$ & 52 & 220 & 40 & 359 & 1244 & 1915 & 6,4 \\
\hline
\end{tabular}

.. = nincs adat. Forrás: EMMI 2012, 36.; NEM 2011, 31.

a felvételi rendszer folyamatos átalakulása ${ }^{9}$ több esetben is kedvezményezett helyzetbe hozta a külhoni magyar hallgatókat. Ez a migrációt serkentő tényezőként hatott, és nyilvánvalóvá vált, hogy az itt tanuló diákok többsége nem kíván hazatérni szülőföldjére. Az ezredfordulón végrehajtott reform során ezért garanciákat építettek az ösztöndíjrendszerbe, amelynek értelmében a támogatásban részesülő hallgató szerződésben vállalta, hogy a képzés után hazatér. Az állam azonban nem ellenőrzi a hallgatói szerződésben foglaltak betartását, és - egy szakkollégiumi igazgató szerint - nem volt példa arra, hogy bárkivel, aki nem tért haza, visszafizettették volna az ösztöndíjat. Ennek következtében sem a szerződés megléte, sem az ösztöndíjkeret folyamatos csökkentése nem mérsékelte a migrációt (Erőss, Filep, Rácz, Tátrai, Váradi, Wastl-Walter 2011, 6-7.).

A fentiek rávilágítanak a magyarországi nemzet- és migrációs politika gyakran elemzett ellentmondásosságára: miközben e politika hivatalos célja a határon túli magyar kisebbségek szülőföldön való megtartása, a magyarországi demográfiai és munkaerö-piaci problémák kezelésének legfontosabb, a legkevesebb költséggel és konfliktussal járó eszköze a határon túli, elsősorban kvalifikált magyarok migrációjának támogatása - például az állampolgárság könnyített megadásával (lásd többek között Feischmidt, Zakariás 2010; Kováts 2004; Tóth 2005). E kettősség a legfrissebb nemzetpolitikai stratégiákban is megjelenik: „A magyar nemzetpolitika alapvetésnek tartja, hogy a külhoni magyar közösségek a szülőföldjükön szeretnék megőrizni magyarságukat. Magyarország ehhez ter- 
mészetesen segítséget nyújt. (...) Ugyanakkor Magyarország nem tud és nem is szeretne szembemenni azokkal a nemzetközi tendenciákkal, amelyek a mobilitás növekedését jelzik." (KIM é.n., 13.)

Az oktatási statisztikához hasonló kép rajzolódik ki akkor, ha a Magyarországon tartózkodó, illetve a bevándorló szerb állampolgárokat a bevándorlásuk célja szerint vizsgáljuk. Bár a két adatsor számszerüen nem összevethető, ${ }^{10}$ a tendencia mégis ugyanaz: a Magyarországra továbbtanulási szándékkal érkező szerb állampolgárok száma ingadozásokkal, de növekszik (különösen 2007 óta). Feltűnő, hogy a magyarországi gazdasági válság kitörése óta folyamatosan csökkenő intenzitású bevándorláson belül a tanulási céllal érkezők részesedése egyre jelentősebb, az elmúlt években már $40 \%$ feletti volt (2. táblázat). A számok ingadozásában fontos szerep jut a magyar állampolgárság megszerzésének, amellyel a hallgató kikerül a vizsgált hivatalos adatbázisokból. Valószínủleg ez áll a 2011 és 2012 közötti változások hátterében is, hiszen ekkor már érzékeltethette hatását a 2010-ben elfogadott kedvezményes honosítási törvény, amelynek nyomán a korábbinál több határon túli magyar jutott magyar állampolgársághoz.

A Vajdaságból Magyarországra irányuló tanulmányi célú migráció földrajzilag meglehetősen koncentrált mintázatú. Az Educatio Nonprofit Kft. ${ }^{11}$ felsőoktatási adatbázisa ${ }^{12}$ alapján 2005 és 2010 között 2181 szerb állampolgárságú hallgató nyert felvételt a magyarországi felsőoktatásba, közel kétharmaduk a Dél-alföldi régióban folytatja tanulmányait. A legtöbb szerbiai (vajdasági) fiatal Szegedre (53,1\%), Budapestre (18,8\%), Pécsre (5,9\%) és Gödöllőre (0,9\%) nyert felvételt. A Budapesti Corvinus Egyetem (BCE) Zentán működő kihelyezett kertészmérnöki képzésére 342 főt $(15,7 \%)$ vettek fel ${ }^{13}$ (1. ábra). A köznevelési információs rendszer (KIR) rendelkezésünkre álló 2010/2011-es adatai hasonló koncentráltságról tanús-

2. táblázat: Továbbtanulási céllal bevándorló, illetve Magyarországon tartózkodó szerb állampolgárok

Educational immigrants and citizens of Serbia residing in Hungary

\begin{tabular}{ccccc}
\hline Év & $\begin{array}{c}\text { Továbbtanulási céllal bevándorló } \\
\text { szerb állampolgárok }\end{array}$ & $\begin{array}{c}\text { Tanulmányi céllal Magyarországon tartózkodó } \\
\text { szerb állampolgárok (január 1-jén) }\end{array}$ \\
\cline { 2 - 5 } & száma & $\begin{array}{c}\text { az összes szerb állam- } \\
\text { polgárságú bevándorló } \\
\text { \%-ában }\end{array}$ & száma & $\begin{array}{c}\text { az összes itt tartózkodó } \\
\text { szerb állampolgár } \\
\text { \%-ában }\end{array}$ \\
\hline 2004 & 334 & 21,1 & 5,4 \\
2005 & 242 & 22,1 & 672 & 3,8 \\
2006 & 261 & 10,7 & 520 & 4,6 \\
2007 & 276 & 6,3 & 552 & 4,4 \\
2008 & 498 & 12,1 & 554 & 4,3 \\
2009 & 352 & 29,1 & 739 & 4,3 \\
2010 & 424 & 42,5 & 738 & 6,5 \\
2011 & 385 & 44,3 & 1119 & 6,9 \\
2012 &.. &.. & 1121 & 6,3 \\
\hline
\end{tabular}

.. = nincs adat. Forrás: Demográfiai évkönyvek adatai alapján saját szerkesztés. 
1. ábra: A magyar felsőoktatásba jelentkező szerb állampolgárok az oktatás helyszíne szerint, 2005-2010 (fó)

Serbian citizens applying in the Hungarian higher education, according to the place of education, 2005-2010

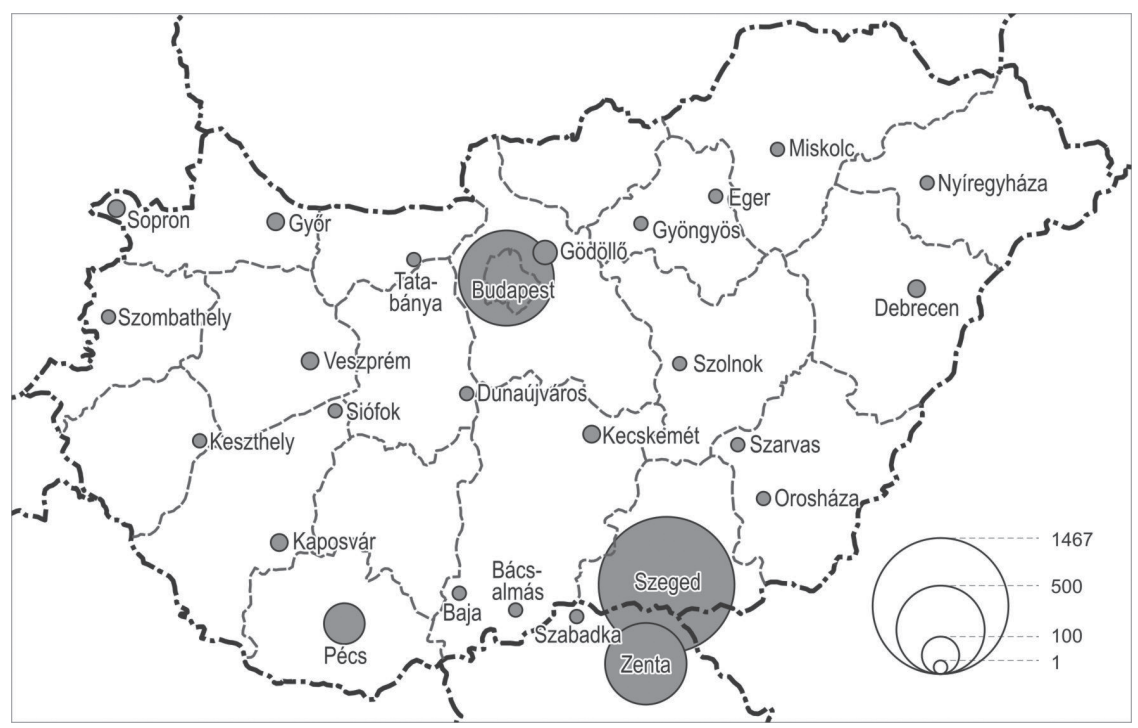

Forrás: Educatio Nonprofit Kft. adatbázisa alapján Takács Zoltán szerkesztése

kodnak: ebben a tanévben a közoktatásba felvett 587 szerb állampolgárságú tanuló 54\%-a a Dél-alföldi régióban (elsősorban Szegeden) tanult.

A hallgatók területi megoszlását - láthatóan - a Vajdasághoz való földrajzi közelség jellemzi. Szeged kiemelkedő szerepet tölt be e folyamatban (Erőss, Filep, Rácz, Tátrai, Váradi, Wastl-Walter 2011; Takács, Kincses 2013), hiszen mind a köz-, mind a felsőoktatásban minden második vajdasági diák Szegedet választja. A földrajzi közelség mellett ebben természetesen a város diverzifikált, jó hírü oktatási szolgáltatásai is közrejátszanak. Így napjainkban Szeged oktatási vonzáskörzete átnyúlik a határokon és kiterjed a környező, elsősorban vajdasági, kisebbrészt romániai magyarlakta területekre. A vizsgált folyamat bár országhatárokat keresztez, mégis nehezen értelmezhető nemzetközi migrációként: sokkal inkább a nagyváros és vonzáskörzete között lebonyolódó mozgásként, ami egyre inkább helyreállítja a határok által szétszabdalt természetes kapcsolatokat.

\section{Vajdasági szemszögből}

Vajdasági magyar szemszögből a fent vázolt folyamat teljesen másként néz ki. A Magyarországra irányuló felsőoktatási migráció a vajdasági magyar egyetemisták, főiskolások 20-25\%-át érintette a 2000-es évek közepén (Gábrity Molnár 2007a, 116.). Ez az arány fokozatosan növekszik, és napjainkra 30-35\%-ra emel- 
kedett (Szügyi, Takács 2011). A Magyarországgal való köz- és felsőoktatási kapcsolatok aszimmetrikusak: a Vajdaságból irányulnak Magyarország felé, az ellenkező irány gyakorlatilag nem létezik.

A vajdasági magyar fiatalok felsőoktatási tanulmányi célú migrációjában az átlagosnál magasabban kvalifikált szülők gyermekei vesznek részt (Erdei 2005). Az Identitás Kisebbségkutató Műhely nem reprezentatív, 370 feldolgozott kérdőívre épülő felmérése szerint a Magyarországon tanuló vajdasági egyetemisták szüleinek iskolai végzettsége jóval magasabb, mint azoké, akik Szerbiában folytatják egyetemi tanulmányaikat. ${ }^{14}$ Ugyanezen kutatás szerint a Magyarországon továbbtanulók körében magasabb a gimnáziumot végzettek aránya, mint a Szerbiában továbbtanulóknál. Az eredmények alapján a kutatók azt a hipotézist fogalmazták meg, hogy „a vajdasági magyar elit többsége Magyarországon iskoláztatja gyermekét" (IDKM 2010,4.). A kutatás eredményei a migrációs hajlandóság tartósan magas szintjére is felhívják a figyelmet (IDKM, 2010, 8.).

A magyarországi felsőoktatásban továbbtanuló szerb állampolgárok elsősorban a Vajdaság északi, magyarok által nagy arányban lakott községeiből (opština) származnak. Az Educatio Nonprofit Kft. adatbázisa szerint 2005 és 2010 között a legnagyobb kibocsátó községek Szabadka (636 fö, az összes Magyarországon tanuló 22,7\%-a), Magyarkanizsa (552 fö, 19,7\%), Zenta (489 fö, 17,5\%), Topolya (279 fo, $10 \%$ ) és Ada (217fó, 7,8\%). A 2. ábrán jól látható, hogy a kibocsátó területeknél - a célterületekhez hasonlóan - meghatározó tényező a Magyarországhoz való földrajzi közelség, ugyanakkor ez egybeesik a magyar etnikai tömb területével. Bár a szórványterületekről is érkeznek hallgatók Magyarországra, de a magyar népesség számához viszonyítva sokkal kevesebben, mint az etnikai tömb területéről. Ráadásul a Vajdaság déli részeihez Újvidék felsőoktatási központja közelebb van, mint Szeged. Ha a Magyarországon tanuló vajdasági hallgatókat a kibocsátó terület magyar lakosságához viszonyítjuk, akkor azt találjuk, hogy minél nagyobb a magyar lakosság aránya, annál magasabb arányban tanulnak Magyarországon a föiskolások és egyetemisták. ${ }^{15}$ Tehát összességében azt láthatjuk, hogy Szegedhez éppen azok a területek vannak a legközelebb, ahol a magyarok aránya tartományi és helyi szinten is a legmagasabb, ráadásul e területeken a viszonylagos etnikai homogenitás következtében általában a szerb nyelv ismerete is alacsonyabb szintü, így nagyobb az igény a magyar nyelvű továbbtanulási lehetőségek iránt (Gábrity 2008b). E hatások egymást erősítik, és a vizsgált folyamatot tovább fokozzák.

Bár a határon túli magyar hallgatók számára a magyarországi ösztöndíjrendszert többek között azért hozták létre az 1990-es évek elején, hogy a küldő országokban anyanyelven elérhetetlen szakokra képesítsen, ez már az 1990-es években sem valósult meg (Horváth 2004, 60.), továbbá napjainkban sem az határozza meg a tudományterületi megoszlást, hogy a kibocsátó régiókban mire van szükség, hanem az egyéni érdeklődés és a karrierlehetőség.

A Vajdaságból érkező felvételizők tudományterületi ${ }^{16}$ megoszlására 2005 és 2010 között a következő sorrend volt jellemző: agrártudományok (20\%), bölcsé- 
2. ábra: A magyarországi felsőoktatási intézményekbe jelentkező vajdaságiak a kibocsátó községek (állandó lakóhely) szerint, 2005-2010

People from Vojvodina applying for studies in Hungarian higher education, according to their place of residence, 2005-2010

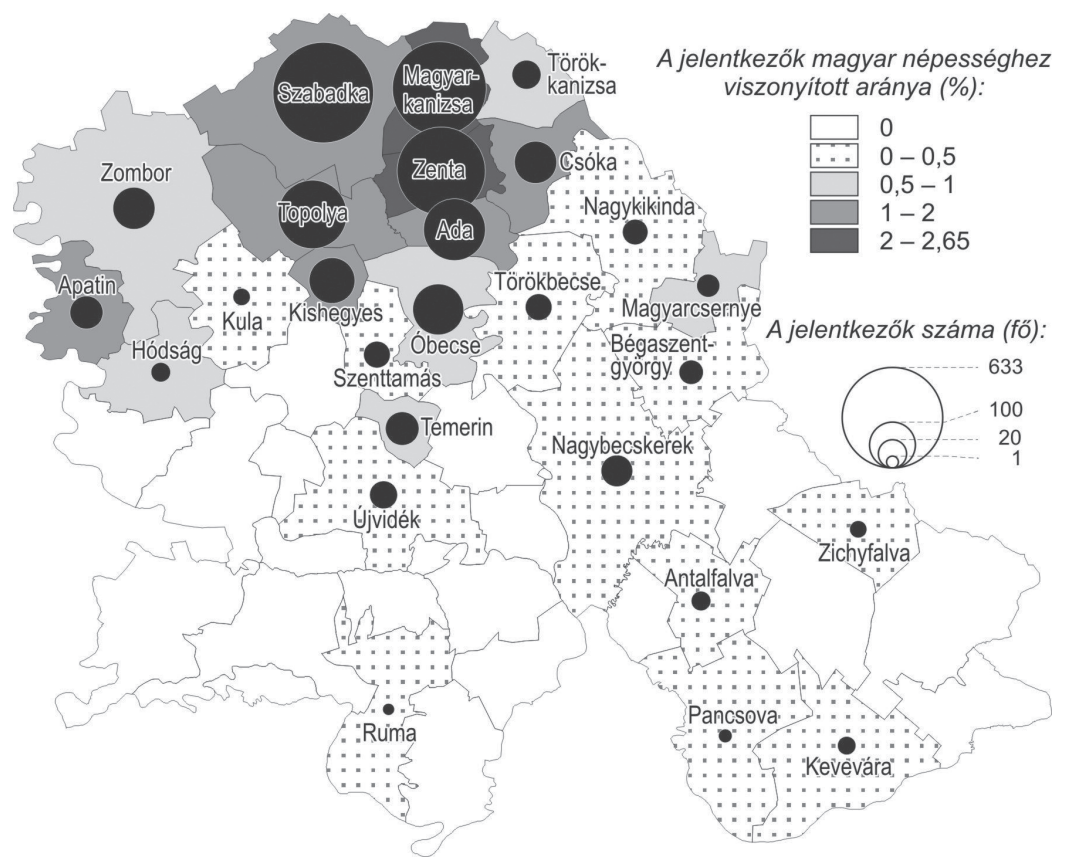

Forrás: Educatio Kft adatbázisa és a 2011-es szerb népszámlálás alapján a szerzők szerkesztése

szettudományok (14\%), egészségügyi és orvostudományok (12\%), természettudományok (10\%) és informatika (8\%). Természetesen az agrárterület kiemelkedő szerepe elsősorban nem a Vajdaság kedvező agráradottságaira és az ebben rejtőző boldogulási lehetőségekre vezethető vissza, hanem a BCE zentai kihelyezett kertészmérnöki képzésére, amely magyarországi diplomát ad, mégsem kell hozzá elhagyni Szerbiát, vagyis földrajzi mobilitás nélkül kínál társadalmi mobilitást.

Takács a Szerbiában tanuló vajdasági magyarok kedvezőtlen tudományterületi megoszlását hangsúlyozza, ugyanis az otthon tanulók a helyi „szűkös felsőoktatási kínálatból" válogatnak. Tartományi szinten a vajdasági magyar hallgatók ${ }^{17} 44,7 \%$-a társadalom- és bölcsésztudományok, 28,2\%-a pedig technika- és technológiatudományok területén szerez felsőoktatási végzettséget (Takács 2010). A magyarok által nagyobb arányban lakott észak-vajdasági, határ menti régióban a helyzet még kedvezőtlenebb. A régióban maradó fiatalok negyede műszaki végzettségü, negyede tanító és tanár, negyede pedig közgazdász-menedzser (ez egyben az Észak-Vajdaságban elérhető, magyar nyelvü felsőoktatási kínálatot is tükrözi). A helyi felsőoktatás sem a magyar kisebbség igényeit és érdekeit, sem a régió társadalmi-gazdasági változásait, sem a munkaerőpiac elvárásait nem képes követni (Szügyi, Takács 2011). ${ }^{18}$ 
Becslések szerint a tanulmányaik befejezése után a Magyarországon tanulók mindössze 30-50\%-a tér vissza szülőföldjére (Szügyi, Takács 2011, 296.), ${ }^{19}$ így a külföldi (magyarországi) tanulás, illetve a továbbtanulás migrációs csatornának tekinthető, amely az áttelepedés vagy a Nyugat-Európába való továbbvándorlás első lépéseként is értelmezhető (Fercsik 2008). Éppen ezért e jelenség komoly aggodalmakat kelt a vajdasági magyar közösségben, amelyet egyaránt értékelnek demográfiai problémaként és agyelszívásként, amely végső soron a kisebbségi magyar közösség fennmaradását veszélyezteti (lásd például Fercsik 2008; Gábrity Molnár 2007a, 2007b, 2008b; IDKM 2010; Mirnics 2001; Rózsa 2011).

A problémát a vajdasági magyar közösség képviseletében a Magyar Nemzeti Tanács (MNT) a saját nemzetpolitikai eszközeivel igyekszik megoldani. ${ }^{20} \mathrm{Az}$ MNT biztosítani szeretné a magyarok minél magasabb iskolázottságát, képzését, elhelyezkedését, szülőföldön való boldogulását. Az MNT hangsúlyozza a vajdasági felsőoktatás jó minőségét, ezen túlmenően a 2011/2012-es tanévtől anyagi ösztönzést (120-150 euró havi ösztöndíj) és egyéb - mentorálási, majd elhelyezkedési - segítséget is nyújt a helyben maradó fiataloknak ${ }^{21}$ (MNT 2010). A szülőföldön tanulás mellett szóló érveik a külföldről való visszatérés nehézségeit hangsúlyozzák: „Az, aki Magyarországon tanul, gyakran megfeledkezik arról, hogy sok szempontból felégeti maga mögött az itthoni munkavállalás lehetőségét (...)" (Korhecz 2012. 7.), ami utal az egyetemi évek alatt kialakított kapcsolatrendszer és a szerb nyelvismeret fontosságára. Korhecz érvelése azonban ellentmondást is rejt magában, hiszen a diákok jelentős hányada éppen a szerb nyelv nem megfelelő ismerete miatt folytatja tanulmányait Magyarországon, magyar nyelvű tudásukkal pedig - ahogyan a magyarországi továbbtanulás előtt is - vagy nem, vagy csak korlátozottan lesznek versenyképesek a szerbiai/vajdasági munkaerőpiacon. Az MNT oktatásfejlesztési stratégiája a hiányszakmákat továbbra is magyarországi, de Szerbiában szerződött és folyósított támogatási és pályázati eszközökből, szerbiai felsőoktatási intézményekben szerzett diplomákkal próbálja biztosítani. Ez a reményeik szerint gyökeres változást eredményez majd, bár az ösztöndíjrendszer átalakításának hatásai csak hosszabb távon lesznek mérhetők, és az eredményesség természetesen nagyban függ majd az aktuális szerbiai gazdasági-társadalmi viszonyoktól. Mindezek következtében a vajdasági magyar nemzetpolitikai törekvések korlátozott erőtérben mozognak.

Ha arra keressük a választ, hogy miért is nem akar a vajdasági magyar fiatalok jelentős része helyben továbbtanulni, miért folytatják tanulmányaikat Magyarországon, nem elég csak a makroszintet, a (nemzet)politikát, az intézményeket vizsgálni. Ezért a következőkben a hangsúlyt az egyéni, családi szintre helyezzük, és Magyarországon tanuló vajdasági diákokkal készült interjúink alapján vizsgáljuk a továbbtanulásról, áttelepedésről szóló döntések hátterét. 


\section{A magyarországi továbbtanulásról és letelepedésről szóló döntések háttere}

Az 1990 óta eltelt bő két évtized során a vajdasági családokban a gyerekek magyarországi továbbtanulását érintő döntéseket a változó politikai, gazdasági körülmények, a társadalmi mobilitás és boldogulás perspektívái egyaránt befolyásolták. A kilencvenes években, a feléledő nacionalizmus, a polgárháború, az embargó és a NATO-bombázások idején a magyarországi közép- és felsőfokú tanulmányok melletti döntésben a biztonság volt az elsődleges - noha nem kizárólagos - szempont a fiatalok és a családok számára. A magyarországi iskoláztatás több tekintetben is a biztonságot jelentette; a közép- és felsőfokú oktatásban való részvétellel a férfiak el tudták kerülni a katonaságot (fizikai biztonság); a fojtogató nacionalista légkörrel szemben a szellemi szabadságot, a gazdasági válsággal és kilátástalansággal szemben pedig a gazdasági biztonságot kínálta a magyarországi továbbtanulás. Fontos tudnunk, hogy a NATO-bombázások időszakában az iskolák egy része bezárt, így a továbbtanulás Szerbiában semmilyen szinten nem volt biztosított. Az ezredfordulót követően azonban a megélhetés, boldogulás, karrierépítés lehetőségei váltak a tanulmányi célú migrációt ösztönző perdöntő tényezővé, a magyarországi diploma pedig 2004 óta felértékelődött, hiszen az uniós munkaerőpiacra való belépés esélyével kecsegtet. Ugyanakkor a magyarországi diploma iránti kereslet az elhúzódó magyarországi gazdasági válság idején sem csökken(t), ami - Szerbia még rosszabb gazdasági helyzetén kívül - azt mutatja, hogy a gazdasági szempontok a döntésben egyáltalán nem kizárólagosak.

A magyarországi továbbtanulás melletti vonzó és taszító tényezőkről kutatási tapasztalataink megerősítették mások eredményeit (bővebben lásd erről Erőss, Filep, Rácz, Tátrai, Váradi, Wastl-Walter 2011). A legfontosabb tényezők között a vajdasági magyar nyelvű felsőoktatási képzés lehetőségeinek szűkösségét, illetve hiányát kell említenünk (pl. Gábrity Molnár 2007b; Szügyi, Takács 2011; Takács 2009), ami egyúttal a szerbiai társadalomban való boldogulás, a társadalmi mobilitás esélyeinek korlátozott voltát is előrevetíti. A szerb nyelv ismerete, használata természetesen függ az adott család, a szomszédság, a település, a régió etnikai összetételétől, de interjúink alapján úgy tűnik, hogy a szerb nyelvű felsőoktatási tanulmányok a mégoly jó nyelvtudással rendelkező fiataloktól is rendkívüli erőfeszítéseket követelnek. A nyelvtudás, a nyelvi kompetenciák alapvető szerepet töltenek be a migrációs döntésekben; a szerb államnyelv hiányzó vagy nem megfelelő ismerete egyfelől, a magyar nyelvü képzésben való részvétel lehetősége másfelől a tanulmányi célú migrációt tápláló tényezők. Az interjúk rávilágítottak arra is, hogy a támogató - rokonokból, volt iskolatársakból, ismerősökből álló, az áttelepüléssel járó nehézségek kezelésében segítséget jelentő -, egyben migrációs mintaként szolgáló hálózatok milyen fontos szerepet játszanak a tanulmányi célú migráció fenntartásában. S ugyanígy, a vonzó és a migrációt tápláló tényezők között a széles, jó minőségű magyarországi képzési paletta mellett a magyar állam ösztöndíjrendszert, kol- 
légiumi hálózatot kínáló támogatási politikája ${ }^{22}$ vagy - például Szeged esetében - akár a földrajzi közelség ${ }^{23}$ is fontos helyen szerepel.

A végső le- vagy visszatelepedésről hozott döntés sok esetben egy összetett, hosszabb folyamat eredményeként születik. Beszélgetőpartnereink egy része az áttelepedés szándékával kezdte meg magyarországi tanulmányait, mások viszont a hazatérést tervezték, legalábbis nem zárták ki annak lehetőségét. Voltak, akik a diploma megszerzését követően egyszer vagy többször is visszatértek a szülőföldjükre, a két ország között mozogva keresték a jobb megélhetési lehetőségeket, s ha megtelepedtek is Magyarországon, nem tekintik feltétlenül véglegesnek döntésüket (Erőss, Filep, Rácz, Tátrai, Váradi, Wastl-Walter 2011, 10-11.), mások életútjában egy-egy harmadik országba tett kitérő is előfordul.

A (végleges) magyarországi letelepedés mellett érvelve beszélgetőpartnereink rendre összevetették a két ország között a mobilitási, a megélhetési és a karrierlehetőségekben fennálló különbségeket. Az egyes diplomák (például orvos, mérnök vs. szociológus, magyar logopédus) munkaerö-piaci értékesíthetőségének eltéréseitől eltekintve is alapvető problémát jelent, hogy az esetek többségében még a jelentősebb magyar népességgel rendelkező településeken is olyan szakembereket keresnek, akik jól beszélnek szerbül. A magyarországi diploma szerbiai honosítása hosszú évekig elhúzódhat, s addig az érintettek, ha visszatelepednek, a tényleges végzettségüknél alacsonyabb beosztásban s ennek megfelelő bérezésért tudnak csak elhelyezkedni. Emellett - a felsőfokú tanulmányok ideje alatt kialakított - kapcsolatrendszerük is elsősorban Magyarországhoz köti őket, ott tudják csak ezeket a kapcsolatokat gazdaságilag is kihasználni (pl. munkakereséskor). Hallottunk panaszokat a szerbiai, magyarokkal szembeni munkaerő-piaci diszkriminációról; magasabb, jól fizetett beosztásokba csak szerb munkavállalók (gyakran: a háborúk idején Vajdaságba menekültek) kerülhetnek, képzettségüktől, rátermettségüktől függetlenül. Beszélgetőpartnereink jószerivel egyöntetűen kedvezőtlennek és kiszámíthatatlannak tartották a szerbiai gazdasági, munkaerö-piaci, társadalmi és politikai helyzetet, amely a magyarországi diplomát szerzett magyar kisebbségiek számára nem kínál valódi esélyt és perspektívát. Az is igaz, hogy néhány diplomás számára a nagyvárosok, főként Budapest által kínált kulturális lehetőségek fényében szűkösnek, kis léptékűnek tűnik a vajdasági világ.

$\mathrm{Az}$ anyagi boldoguláshoz, szakmai előmenetelhez, karrierhez kapcsolódó szempontok mérlegelése mellett a társas kapcsolatok alakulása, mindenekelött a házasság és a gyermekek születése, de a régi-új barátságok, munkatársak hálózata is meghatározóak a migráció kimenetelére. A végleges magyarországi letelepedést szolgáló döntést segítheti, ha időközben a testvérek, barátok is átköltöztek, ha az idősödő szülőkön, nagyszülőkön kívül nem maradt otthon senki. A hazatérés évekig nyitott lehetőségét lezárhatja a házasság egy magyarországi partnerrel, de ugyanígy a vajdasági társ is hazaszólithat Magyarországról. Bárhol is éljen a család, a gyerekek megszületésével alapvetően megváltoznak a migrációs perspektívák: mellettük, velük már nem könnyü és nem is vágyott a mozdulás. 


\section{Összegzés}

A Vajdaságból Magyarországra irányuló tanulmányi célú migráció napjainkra az egyik legjelentősebb vándorlási típus lett. Az elmúlt két évtizedben belső struktúrája átalakult, a közoktatásról a hangsúly egyértelműen a felsőoktatásra helyeződött - összhangban a regionális és globális folyamatokkal. E migráció elsősorban a vajdasági magyar kisebbséget, annak is elsősorban magasan kvalifikált csoportjait érinti, így vajdasági magyar szemszögből a folyamat egyértelműen az agyelszívás veszélyeit hordozza magában.

Napjainkban a vizsgált tanulmányi célú migráció egyszerre etnikai és gazdasági meghatározottságú folyamat. A kilencvenes évek háborús viszonyainak elmúltával is tartósak azok a vonzó és taszító tényezők, illetve azok a határon átnyúló, transznacionális migráns hálózatok, amelyek táplálják, azaz nem csak segítik, de támogatott, legitim családi és egyéni stratégiává is teszik a tanulmányi célú migrációt. Bár a transznacionális migráció e formája a kimenetelét tekintve nyitott (áttelepedés, visszatérés, harmadik országba költözés, cirkuláció), az esetek többségében a szülöföldről való „végleges” távozás első lépcsőfokának tekinthető.

A tanulmányi célú migráció már a kezdetektől, azaz a rendszerváltás óta nemzetpolitikai erőtérben zajlik, a politika alakította ki induló kereteit (pl. magyarországi ösztöndíjrendszer). Azonban a politikának befolyásoló szándéka ellenére sem sikerült érdemben és közvetlenül beleszólnia a tanulmányi célú migráció nagyságába, irányába és a visszatérésbe - bár a keretek alakításával természetesen hatott rá. A jelenlegi magyarországi nemzetpolitika ellentmondásos, nem lehet pontosan látni, mi is az elsődleges célja: a hivatalosan képviselt szülőföldön való boldogulás elősegítése vagy pedig az áttelepedés hallgatólagos ösztönzése. A vajdasági magyar nemzetpolitika pedig - bár 2011-ben jelentősen változtatott a vajdasági ösztöndijrendszeren - egyelőre nem tudta elérni a céljait (szülőföldön tanulás, illetve visszatérés), ugyanakkor a változás eredményei csak néhány év múlva látszódnak, s azon is múlnak majd, hogy a Szerbiában megszerzett diploma milyen boldogulási, mobilitási lehetőségeket nyit meg a vajdasági magyar fiatalok előtt.

\section{Jegyzetek}

1 Értelmezésünkben a Magyarországon tanuló vajdasági középiskolások, egyetemi hallgatók transznacionális migránsoknak nevezhetők, hiszen egyszerre két országban élnek, kapcsolataik két országhoz kötik őket, ám eltérő módon és intenzitással (Erőss, Filep, Rácz, Tátrai, Váradi, Wastl-Walter 2011, 5.). A migránsok többes kötődése és szerteágazó kapcsolataik később tőkeként is hasznosíthatók a célország munkaerőpiacán, ahol a külföldi diákok legfontosabb versenyelőnye többnyelvűségükben, alkalmazkodóképességükben rejlik, továbbá abban, hogy a küldő és fogadó ország szokásaiban és kultúrájában egyaránt otthonosan mozognak (Salt 2005, 31.). A transznacionális megközelítésben a tanulmányi célú migráció kimenetele nyitott, többszöri oda-vissza mozgás, cirkuláció jellemezheti (Illés 2012) vagy egyfajta „lebegő” állapot, életmód, a készenlét a vissza- vagy továbbvándorlásra (Feischmidt, Zakariás 2010, 
159.; Szentannai 2001, 126.). Ennek megfelelően a tanulmányi célú migráció nem egyirányú folyamat, és sokszor egy hosszú távú migráció első lépcsőjének tekinthető.

2 Az agyelszívás (brain drain) fogalma az 1950-es években született meg; később számos kifejezés helyettesítette, finomította, a jelenséget. Így folyamatosan bővült az agyelszívás fogalmával társított kifejezések palettája: emberi erőforrás/tőke kivándorlása, magasan képzettek migrációja, agygyarapodás (brain gain), agycsere (brain exchange), agyvesztés (brain waste), agyak körforgása (brain circulation) (Csanády, Személyi 2006, 80.).

3 A Kelet-Közép-Európa országaiban született felsőfokú végzettségűek közül az ezredfordulón átlagosan 10-15\% az OECD tagállamaiba vándorolt ki. A listát a balkáni országok vezetik (Macedónia, Horvátország és Bosznia-Hercegovina), ahol a felsőfokú végzettségű lakosság 25-30\%-a emigrált. E jelenséget egyes kutatók már „brain flight”-nak nevezik (lásd Mihailović 2004). Szerbiában - déli szomszédjaihoz képest - ez az érték alacsony (17\%), míg Magyarország a régiós átlag körül helyezkedik el (13\%) (Docquier, Marfouk 2005, idézi Csanády, Személyi 2006, 84.).

4 Ugyanakkor az agyelszívás elleni - már megvalósult - intézkedésnek tekinthető a határon túli magyar hallgatók „,röghöz kötése”, azaz esetünkben a 2001-es évtől a diákokkal kötött szerződések a hazatérésről (lásd Epare 2008).

5 2010-ben a teljes magyar felsőoktatásban (nappali és esti tagozat, távoktatás) részt vevő külföldiek aránya azonban az említett értéknél jóval alacsonyabb (4,5\%), még mindig elmarad az OECD-országok 8\%-os felsőoktatási átlagától (OECD 2012).

6 A magyarországi adatok forrása az EMMI (2012).

7 A szegedi középiskolákba a háborús időszakokban (1992-1995, 1999-2000) mintegy 400 külföldi diák ingázott. A délszláv polgárháború és a koszovói válság közötti időszakban ez az érték szinte azonnal drasztikusan lecsökkent, a 2000-es évek elejétől egy kevésbé jelentős, de folyamatos csökkenés volt jellemző (Jóri 2007, 282.).

8 Az adatok sokszor hiányosak és ellentmondásosak. Pl. míg az Oktatási Évkönyv az 1998/1999es tanévben mindössze 281 szerb állampolgárról tud a felsőoktatásban, addig Szentannai $(2001,118$.$) a Márton Áron Szakkollégium adataira támaszkodva 561$ vajdasági ösztöndíjasról tud az 1997-1999-es időszakra, ami - az ösztöndíjasok és az összes határon túli magyar hallgató számának távolodása miatt (Szentannai 2001, 117.) valószínűtlennek tűnik. A statisztikák megbízhatóságáról, valamint a számbavétel problémáiról lásd még Horváth 2004, 62-64.

9 A kilencvenes évek elején bevezetett rendszerben a határon túli közösségek - az általuk létrehozott ösztöndíjtanácsokon keresztül - a kisebbség igényeit mérlegelve döntenek arról, hogy kik és milyen szakirányon folytathatják tanulmányaikat magyarországi felsőoktatási intézményben, magyar állami ösztöndíjban részesülve (Erőss, Filep, Rácz, Tátrai, Váradi, WastlWalter 2011, 6.). A cél a hiányszakmák pótlása volt, így a magyar ösztöndíj-politikának köszönhetően (melynek olyan részelemei voltak, mint a Nemzeti Előkészítő Intézet (NEI) és a Márton Áron Szakkollégium) a legjobb eredményeket felmutató fiatalok Magyarországon folytathatták tanulmányaikat (az országos, egységes felvételin szerzett pontszámok alapján). Később ún. „miniszteri ösztöndíjban” részesülhettek a határon túli magyar hallgatók, a rendes felvételi eljárások során. Napjainkban a magyar felsőoktatást még mindig vonzóvá teszi, hogy a vajdasági diákokat az otthoni érettségi pontok alapján veszik fel, míg Szerbiában szerb nyelven kellene felvételi vizsgát tenniük (a magyarországi felsőoktatási intézményekben tanuló határon túli magyar diákok támogatásáról részletesebben Epare 2008; Erdei 2005; Horváth 2004; Molnár 2008).

10 A KSH adatsora nem is fedheti az oktatásért felelős minisztériumok adatait, hiszen elsősorban az idegenrendészeti eseteken alapul, amelyek nem terjednek ki egyes távoktatásos vagy időszakos képzésekre, továbbá a nappali tagozatos hallgatók közül is többen az ingázással kerülik ki a bürokráciát (Horváth 2004, 62-63.). Ezen túlmenően is óvatosan kell kezelni az adatbázist, hiszen például 2011-ben a szerb állampolgárok harmadánál ismeretlen volt a tartózkodás célja.

11 Az Educatio Társadalmi Szolgáltató Nonprofit Kft. külföldi hallgatókat tartalmazó adatbázisát Dr. Veroszta Zsuzsanna és Fodor Szabolcs bocsátotta rendelkezésünkre, amiért ezúton is köszönetet mondunk. 
12 Az adatbázisban szereplő hallgatók (N=2806) 85\%-a általános és normál felvételi eljárással, 1\%-a keresztféléves eljárással, 14\%-a pótfelvételi eljárással jelentkezett a felsőoktatási intézményekbe a 2005-2010-es időszakban. A felvételizők alapsokaságának nemi megoszlása: 56\% nő, 44\% férfi. Felvételt 2181 hallgató nyert (77\%-os felvételi sikeresség); 84\%-uk tanul Magyarországon, míg 16\%-uk kihelyezett képzésen (Zenta) folytatja tanulmányait. A felvettek 83,4\%-a alapképzésen tanul; többségük nappali munkarendben (71,2\%), esetleg levelező tagozaton (24,9\%), az egyéb munkarendek (távoktatás, esti oktatás) nem jellemzők. A felvételt nyert hallgatók 70\%-a állami finanszírozottként (a vizsgált időszakban 1514 hallgató), 30\% pedig költségtérítéssel tanul Magyarországon (647fó).

13 A fiatalok a magyarországi felsőoktatási követelményekkel összhangban felvételiznek (a magyar központi adatbázisban szerepelnek), tanulmányaikat a BCE kertészmérnöki programja alapján végzik, majd tesznek eleget a vizsgakövetelményeknek; tanulmányuk végeztével a BCE oklevelét szerzik meg, amelyet az Újvidéki Egyetemen tudnak honosítani a Magyar Nemzeti Tanács anyagi támogatásával (részletesen lásd Lengyel 2006).

14 A Magyarországon tanuló egyetemisták körében az egyetemi végzettséggel rendelkező apák aránya 22,6\%, a szerbiai egyetemek hallgatóinál ezzel szemben 7,7\% (IDKM 2010,4.).

15 A tömb- vagy szórványhelyzet fontosságára, illetve a földrajzi távolság szerepére rávilágít a hasonló nagyságú (12,5 ezer fős) magyar lakossággal rendelkező Ada és Nagybecskerek község helyzete, ahonnan 2005 és 2010 között 217, illetve 31 diák felvételizett Magyarországra. Ada községben a magyarok adják a lakosság többségét (75\%), a település távolsága Szegedtől mindössze 73 km, míg Nagybecskerek községben a magyarok aránya 10\%, az opština központjától Szeged $143 \mathrm{~km}$, viszont Újvidék csak $50 \mathrm{~km}$.

16 A felvételi rendszerben használatos néhány „képzési területet” összevontunk (pl. egészségügyi képzési terület és orvostudományi képzési terület); az elemzés során nem a (Magyarországon) hivatalos tudományügyi besorolást használjuk.

17 A Tartományi Oktatási Titkárság adatai szerint a 2009/2010-es tanévben a Vajdaságban tanuló magyar nemzetiségủ hallgatók száma 3152 volt (5,6\%-a a tartományban, állami intézményekben tanuló teljes hallgatói létszámnak N=55 675). A magyar hallgatók 30\%-a szakföiskolákon, 70\%-a az Újvidéki Egyetem egyes karain tanult. 2010-re a magyar nemzetiségüek részaránya jelentősen lecsökkent (2004/2005: 6,9\%, 2009/2010: 5,6\%), míg tartományi szinten a hallgatók száma 22\%-kal nőtt (45 670-ről 55 675-re). A magyar hallgatók száma ugyanakkor (abszolút számokban) változatlan maradt (APV 2011). A folyamatok mögött több ok is állhat: a vajdasági magyarok nagyobb számban iratkoznak be magyarországi felsőoktatási intézményekbe vagy a tartományban múködő (magyarul is oktató) magánkarokra, de a negatív demográfiai trendek is hatással lehetnek ezekre a folyamatokra.

18 A Magyar Nemzeti Tanács mint a vajdasági magyar kulturális autonómia intézménye egyértelműen megfogalmazza a vajdasági magyar közösség oktatásával, képzésével szemben támasztott érdekeit, céljait, igényeit (MNT 2010). Az elsődleges célja a vajdasági magyar közösség képzettségi szintjének emelése, az emigráció megfékezését segítő, szülőföldön történő oklevélszerzés, a vajdasági magyar közösség által megnevezett (reális felmérésekre alapozó) hiányszakmák támogatásával.

19 Az említett 30-50\%-os diplomaszerzés utáni hazatérési arány még mindig viszonylag magasnak számít pl. az erdélyi adatokkal összehasonlítva: Sorbán és Nagy (2001) szerint a '90-es évek utolsó harmadában a Magyarországról Romániába visszatérők aránya 10-20\% volt. A vajdasági visszatérőkre vonatkozó adatokat támasztja alá Józsa (2013), aki az elmúlt tíz évben lefolytatott - a Szekeres László Alapítványhoz benyújtott - honosítási kérelmeket elemezte. Eszerint minden harmadik Magyarországon megszerzett diplomát honosították Szerbiában. Arról nem rendelkezünk adatokkal, hogy hányan tértek haza azok közül, akik diplomájukat nem, vagy nem az alapítvány anyagi és szakmai támogatásával honosították.

20 A határon túli magyarlakta régiók saját nemzetpolitikai fellépése már korábban is megmutatkozott. 1993-ban az erdélyi szakmai szervezetek kérték a magyar államot az ösztöndíjasok számának az (erdélyi) hiányszakmákra való korlátozására (Szentannai 2001, 116.).

21 A Szerbiában készült interjúk alapján az a benyomásunk, hogy a Szerbiában tanuló vajdasági magyar hallgatók nem tudnak a rendelkezésre álló állami ösztöndíj-lehetőségekről. Állami 
ösztöndíjat nem is pályáznak meg a hallgatók, mert „nehéz megkapni”, de sokan nem is ismerik ezt a kategóriát. Vállalati ösztöndíjat említett egy interjúalany, míg a többi hallgató mind (és kizárólag) a szülők anyagi támogatásával végezte tanulmányait. Az is jellemző és általános jelenség, hogy a hallgatók albérletben laktak tanulmányaik során. Nem pályázzák meg a kollégiumot, nem veszik igénybe az állam által adott támogatási lehetőségeket. Ezen eredmények egybecsengenek egy korábbi felmérés eredményeivel, amelyből szintén az derül ki, hogy a Vajdaságban tanuló magyar hallgatók közül sokkal kevesebben részesültek ösztöndíjban és kaptak kollégiumi elszállásolást, mint a Magyarországon tanuló vajdasági fiatalok (Mirnics 2001. 177).

22 A magyarországi továbbtanulás egyik alapvető feltétele a család megfelelő anyagi helyzete, amely még akkor is perdöntő, ha a diákok ösztöndíjban, kollégiumi ellátásban részesülnek. Az interjúk alapján differenciált kép bontakozott ki a családok erőfeszítéseiről. Hallottunk jómódra utaló történeteket: amikor a Magyarországon tanuló egyetemista testvérpárnak a szülei autót vesznek, hogy könnyebben haza tudjanak járni vagy amikor a Szegeden középiskolába járó diákoknak szüleik lakást vásároltak. Másrészt beszéltünk olyan vajdaságiakkal, akiket magyarországi diákéveik alatt szüleik nem tudtak támogatni, ők minden munkaés üzleti lehetőséget megragadtak, hogy tanulmányaikat és tartózkodásukat finanszírozni tudják. Az anyagiak jelentőségére utalt a temerini magyar általános iskola igazgatója, amikor arról beszélt, hogy benyomásai szerint elült a gyerekek szegedi középiskoláztatásának „divathulláma", elsősorban azért, mert nagyon nagy pénzbeli terhet ró a szülőkre.

23 A Szegeden tanuló beszélgetőpartnereink hangsúlyozták, hogy Szeged „nincs olyan messze a lakóhelyemtől”, illetve „nem fárasztó az utazás”, „megéri hazamenni”, mert fontos az otthoni „közvetlenség”, fontos a család.

\section{Irodalom}

APV 2011: Pokrajinski sekretarijat za obrazovanje. Vojvodina, Srbija

Csanády M., Személyi L. (2006): Brain drain. Közelkép a diplomás magyarokról. Századvég, 3., 79-122.

Docquier, F., Marfouk, A. (2005): International migration by educational attainment (1990-2000). Release 1.1. World Bank Policy Research Working Paper

Egedy T., Kovács Z. (2011): Budapest as a destination of migration: the view of transnational creative workers. Hungarian Geographical Bulletin, 2., 161-188.

EMMI (2012): Statisztikai Tájékoztató Oktatási Évkönyv 2011/2012. Emberi Erőforrások Minisztériuma, Statisztikai Osztály, Budapest. http://www.kormany.hu/download/8/f9/b0000/Oktat\%C3\%A1si_ \%C3\%89vk\%C3\%B6nyv_2011_2012.pdf (Letöltés: 2013. február 13.)

Epare C. (2008): A nemzet peremén. Külhoni magyar ösztöndíjasok a fővárosban. In: Szarka L., Kötél E. (szerk.): Határhelyzetek. Külhoni magyar egyetemisták peregrinus stratégiái a 21. század elején. Balassi Intézet Márton Áron Szakkollégium, Budapest, 10-29.

Erdei I. (2005): Hallgatói mobilitás a Kárpát-medencében. Educatio, 2., 334-359.

Erőss Á., Filep B., Rácz K., Tátrai P., Váradi M. M., Wastl-Walter, D. (2011): Tanulmányi célú migráció, migráns élethelyzetek: vajdasági diákok Magyarországon. Tér és Társadalom, 4. 3-19.

Feischmidt M., Zakariás I. (2010): Migráció és etnicitás. A mobilitás formái és politikái nemzeti és transznacionális térben. In: Feischmidt M. (szerk.): Etnicitás. Különbségteremtö társadalom. Gondolat, MTA Kisebbségkutató Intézet, Budapest, 152-169.

Fercsik R. (2008): Szülőföldről a hazába - és vissza? In: Szarka L., Kötél E. (szerk.): Határhelyzetek. Külhoni magyar egyetemisták peregrinus stratégiái a 21. század elején. Balassi Intézet Márton Áron Szakkollégium, Budapest, 124-138.

Gábrity Molnár I. (2007a): Megmaradás, avagy továbbtanulási lehetőségek és szándékok a Vajdaságban - etnikai magatartásvizsgálat. In: Kupa L. (szerk): Tájak, tájegységek, etnikai kisebbségek Közép-Európában. B\&D Stúdió, Pécs, 110-120. 
Gábrity Molnár I. (2007b): Vajdasági magyar fiatal diplomások karrierje, migrációja, felnőttoktatási igényei. In: Mandel K., Csata Zs. (szerk.): Karrierutak vagy parkolópályák? Friss diplomások karrierje, migrációja, felnőttoktatási igényei a Kárpát medencében. Apáczai Közalapítvány, Budapest, 132-172.

Gábrity Molnár I. (2008a): A szerbiai emigráció fél évszázada. http://gabritymolnariren.com/emigra cio.pdf (Letöltés: 2009. november 15.)

Gábrity Molnár I. (2008b): Oktatásunk látlelete. Forum Könyvkiadó, Újvidéki Egyetem Magyar Tannyelvű Tanítóképző Kar, Újvidék, Szabadka

Gödri I. (2005): A bevándorlók migrációs céljai, motivációi és ezek makro- és mikrostrukturális háttere. In: Gödri I., Tóth P. P. (szerk.): Bevándorlás és beilleszkedés. KSH Népességtudományi Kutatóintézet, Budapest, 69-131. (KSH NKI Kutatási Jelentések; 80.)

Gödri I. (2010): Migráció a kapcsolatok hálójában. A kapcsolati tőke és a kapcsolathálók jelenléte és szerepe az ezredvégi magyarországi bevándorlásban. KSH Népességtudományi Kutatóintézet, Budapest

Gredelj S. (2006): Virtuelni povratak „četvrte“ i „pete“ generacije migranata. Filozofija i društvo, 29., $77-88$.

Gürüz, K. (2008): Higher education and international student mobility in the global knowledge economy. State University of New York Press, Albany

Horváth I. (2004): Az erdélyi magyar fiatalok Magyarország irányú tanulási migrációja 1990-2000. Erdélyi Társadalom, 2., 59-84.

IDKM (Identitás Kisebbségkutató Műhely) (2010): Migrációs szándék a vajdasági magyar egyetemisták körében. Zenta. http://www.idkm.org/tanulmanyok/Migracios_szandek1.pdf (Letöltés: 2011. június 11.)

Illés S. (2012): Cirkulációs migráció és integráció. In: Kincses Á. (szerk.): Szerb állampolgárok Magyarországon. PrintPix, Budapest, 146-177.

Iredale, R. (2001): The migration of professionals: theories and typologies. International Migration, 5., $7-26$.

Jóri J. (2007): Határmenti iskolai mobilitás Szeged és Lille térségében: egy kutatás kiindulópontjai. In: Szónokyné Ancsin G. (szerk.): Határok és eurorégiók. SZTE TTK Gazdaság- és Társadalomföldrajz Tanszék, Szeged, 279-284.

Józsa L. (2013): A diplomahonositás útvesztői. (konferencia-előadás) A jó példa ragadós. Vajdasági Magyar Doktoranduszok és Kutatók Szervezete, 2013. március 8.

KIM (é.n.): Magyar nemzetpolitika. A nemzetpolitikai stratégia kerete. Közigazgatási és Igazságügyi Minisztérium, Nemzetpolitikai Államtitkárság. http://bgazrt.hu/_dbfiles/blog_files/3/0000000063 /Magyar\%20nemzetpolitika\%20-\%20A\%20nemzetpolitikai\%20strategia\%20kerete.pdf (Letöltés: 2013. február 12.)

Korhecz T. (2012): Tanuljunk tovább, szerezzünk felsőfokú oklevelet! De hol? In: Lengyel L., Rumenjákovity M. (szerk.): A Magyar Nemzeti Tanács felsőoktatási ösztöndíjprogramja. Magyar Nemzeti Tanács, Szabadka.

Kováts A. (2004): A magyarországi bevándorláspolitika problémái. In: N. Kovács A., Osvát A., Szarka L. (szerk.): Tér és terep. Tanulmányok az etnicitás és identitás kérdésköréból III. Akadémiai Kiadó, Budapest, 297-312.

Lengyel L. (szerk., 2006): 10 éves a kertészmérnök-képzés Zentán 1996-2006. Lux Color Printing, Zenta

Mahroum, S. (2001): Europe and the immigration of highly skilled labour. International Migration, 5., 27-43.

Mihailović S. (2004): Oduzimanje budućnosti - Omladina Srbije u vodama tranzicije. In: Srećko M. (szerk.): Mladi zagubljeni u tranziciji. Centar za proučavanje alternativa, Beograd, 17-37.

Mirnics Zs. (2001): Hazától hazáig. A Vajdaságban és Magyarországon tanuló vajdasági magyar egyetemi hallgatók életkilátásai és migrációs szándékai. In: Gábrity Molnár I., Mirnics Zs. (szerk.): Fészekhagyó vajdaságiak. Magyarságkutató Tudományos Társaság, Szabadka, 163-204.

Molnár Cs. (2008): Érvényesülés, karrierépítés - hazatérés. Hallgatói döntéshelyzetek. In: Szarka L., Kötél E. (szerk.): Határhelyzetek. Külhoni magyar egyetemisták peregrinus stratégiái a 21. század elején. Balassi Intézet Márton Áron Szakkollégium, Budapest, 139-154.

MNT (2010): Oktatásfejlesztési Stratégia. Magyar Nemzeti Tanács, Szabadka 
NEM (2011): Statisztikai Tájékoztató Oktatási Évkönyv 2010/2011. Nemzeti Erőforrás Minisztérium, Oktatási Fejlesztéspolitikai, Statisztikai és Szervezési Főosztály, Budapest. http://www.kor many.hu/download/4/45/50000/Oktat\%C3\%A1si\%20\%C3\%89vk\%C3\%B6nyv-2010.pd (Letöltés: 2012. december 1.)

OECD (2002): Education at a glance. OECD. Paris

OECD (2012): Education at a glance 2012: highlights. OECD Publishing. http://www.oecd.org/edu/higlights.pdf (Letöltés: 2013. február 20.)

Rédei M. (2006): Tanulási célú migráció a világban és itthon. Demográfia, 2-3., 232-250.

Rédei M. (2009): A tanulmányi célú mozgás. Reg-info Kft., Budapest.

Rózsa R. (2011): Migráció és identitás: vajdasági egyetemisták Magyarországon. Közép-Európai Közlemények, 3-4., 166-173.

Salt, J. (2005): Current trends in international migration in Europe. Council of Europe. http://www.grupa484.org.rs/czm/migracioni_potencijal/Current Trends in International Migration in Europe_Salt_\%202005.pdf (Letöltés: 2013. február 18.)

Sorbán A., Nagy K. (2001): Hazajöttem Magyarországról... In: Bodó B. (szerk.): Romániai Magyar Évkönyv. Szórvány Alapítvány, Polis, Temesvár, Kolozsvár, 56-75.

Szentannai Á. (2001): A Magyarországon tanult fiatalok karrierkövetése. Regio, 4., 113-131.

Szügyi É., Takács Z. (2011): Menni vagy maradni? Esélylatolgatás szerbiai és magyarországi diplomával a Vajdaságban. In: Páger B. (szerk.): Évkönyv 2011. PTE Közgazdaságtudományi Kar Regionális Politika és Gazdaságtan Doktori Iskola, Pécs, 283-300.

Takács Z. (2009): Egyetemalapítási helyzetkép a Délvidéken. In: Kötél E., Szarka L. (szerk.): Határhelyzetek II. Kultúra - Oktatás - Nyelv - Politika. Balassi Intézet Márton Áron Szakkollégium, Budapest, 289-313.

Takács Z. (2010): Egyetemalapítási helyzetkép a Délvidéken. In: Somogyi S. (szerk.): Évkönyv 2009. Regionális Tudományi Társaság, Szabadka, 61-85.

Takács Z., Kincses Á. (2013): A Magyarországra érkező külföldi hallgatók területi jellegzetességei. Területi Statisztika, 1., 38-53.

Tóth P. P. (1997): Haza csak egy van? Menekülók, bevándorlók, új állampolgárok Magyarországon, 1988-1994. Püski Kiadó, Budapest

Tóth P. P. (2005): Nemzetközi vándorlás és migrációpolitika. Kisebbségkutatás, 3., 320-329. 